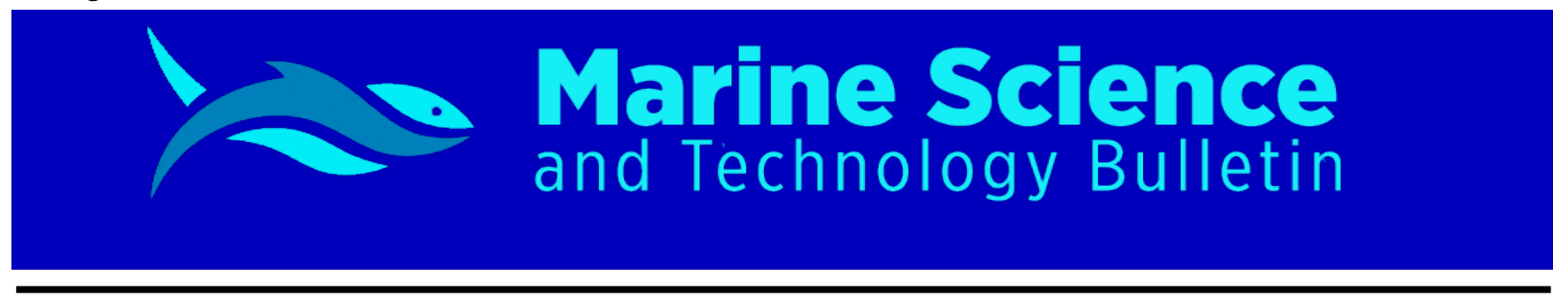

RESEARCH ARTICLE

\title{
An adapted slipping process to exclude jellyfish in the Sea of Marmara purse seine fishery
}

\author{
Nazlı Kasapoğlu $^{1^{*}}$ (D) • Zafer Tosunoğlu (D) • Gökhan Gökçe ${ }^{3}$ (D) \\ ${ }^{1}$ Central Fisheries Research Institute, 61250 Yomra, Trabzon, Turkey \\ ${ }^{2}$ Ege University, Faculty of Fisheries, 35040 Bornova, Izmir, Turkey \\ ${ }^{3}$ Çukurova University, Faculty of Fisheries, 01330 Balcall, Adana, Turkey
}

\section{ARTICLE INFO}

Article History:

Received: 09.02.2020

Received in revised form: 27.02.2020

Accepted: 27.02.2020

Available online: 24.03 .2020

Keywords:
Jellyfish
Slipping process
Purse seine
Sea of Marmara
Turkey

Keywords:

ellyfish

\begin{abstract}
A B S T R A C T
Excluding the jellyfish from the bunt-end is a common slipping process used in the Sea of Marmara purse seine fishery. For this aim, a sheet of netting piece, larger mesh size and thicker diameter, is rigged on the bunt-end of the purse seine net. The jellyfish mass on the netting piece are slipped by rolling over the headline (floating line) after partially hauling or drying-up the net while it is still in the water. In this study, the catch amount of this slipping was roughly estimated with the introduction of the slipping process only used by the purse seiners in the Sea of Marmara. There were eight successful purse seine operations conducted between 8 and 11 September 2018 in depth ranged 77 to $677 \mathrm{~m}$. The percentage of landed species versus to jellyfish varied between $23 \%$ and $85 \%$. The mean landed anchovy amount is $4379( \pm 3756.6) \mathrm{kg}$ for per operation. The mean slipped amount of jellyfish is $3812.5( \pm 2404.4) \mathrm{kg}$. However, both anchovy (99.8\%) and jellyfish (96.3\%) are the vast majority species that landed and slipped, respectively. In the operations totally 100 boxes of anchovy $(1180 \mathrm{~kg})$ unintentionally was slipped with the jellyfish. In addition, two sharks with larger size were slipped to the sea as alive over the floating line of the net. Although slipping practised rarely in Turkey, all the purse seiner in the Sea of Marmara have to use the adapted slipped process to get rid of jellyfish. However, there are no records and scientific findings regarding slipped amount of the jellyfish. For this reason, this study is important to presented preliminary results regarding amount of the jellyfish. In conclusion, this study is extended completely the Sea of Marmara practised to understand the dimensions of jellyfish amount and slipping process.
\end{abstract}

Please cite this paper as follows:

Kasapoğlu, N., Tosunoğlu, Z., Gökçe, G. (2020). An adapted slipping process to exclude jellyfish in the Sea of Marmara purse seine

fishery. Marine Science and Technology Bulletin, 9(2): 75-82

\footnotetext{
* Corresponding author

E-mail address: nazliktu@gmail.com (N. Kasapoğlu)
} 


\section{Introduction}

Purse seining is energy efficient, environmentally friendly fish capture methodology generally targeting large and small pelagic fish shoals (Handegard et al., 2017) with sonar detection, light sources or Fish Aggregation Devices (FAD). Purse seining solely accounts for about $30 \%$ of the world's total fisheries catch (Watson et al., 2006) and approximately three out of four domestic catch of Turkey (TurkStat, 2018). The fishing operations is performed in the Sea of Marmara by 122 purse seiners registered to the various ports and the amount of landings according to the record of the 2017 fishing season varies between 20000-25000 tons (TurkStat, 2018). Anchovy (Engraulis encrasicolus) is dominated fish species landed with 8340 tons. It is followed by European pilchard (Sardina pilchardus) with 5685 tons, two kind of horse mackerels (Trachurus trachurus, T. mediterraneus) with 4447 tons, Atlantic bonito (Sarda sarda) with 1103 tons, bluefish (Pomatomus saltatrix) with 720 tons, mackerel (Scomber scombrus) with 287 tons, grey mullet species with 239 tons, chub mackerel (Scomber japonicus) with 147 tons and garfish (Belone belone) with 93 tons. Almost all of these landed species are captured by the purse seiners.

The Sea of Marmara, connected to the Black Sea and the Aegean Sea by the Straits of Istanbul and Dardanelles, is an inland sea that forming a transition zone and one of the most important migratory routes between the Black Sea and the Aegean Sea for many commercially valuable species (Yıldız and Karakulak, 2016). Additionally, due to the high level of nutrients and plankton abundance, it is reproduction and growth area for many species (Yüksek, 2016).

In recent years, the warning signs of ecological deterioration such as algal blooms, fishery collapse, massive mucilage events, and jellyfish blooms have increased significantly in the Sea of Marmara (İ̧̧inibilir and Yılmaz, 2016). Overfishing as a major anthropogenic impact that causes increasing jellyfish blooms through removing jellyfish predators and competitors (Daskalov et al., 2007). Latest studies also showed that quantities of jellyfish have been increasing in the Sea of Marmara in the last decades and Aurelia aurita is the most important jellyfish species for the basin with yearlong occurrence and prolonged blooms with higher biomass (İşinibilir and Yılmaz, 2016).

Despite advances in sonar technology and highly experienced fishermen, it is currently difficult to determine a reliable quantity and a size-range for the fish before the catch has been densely crowded at the end of the haul (Breen et al., 2012). Purse seines, particularly for small species, are generally considered to be a non-selective fishing gear once a target shoal has been encircled, primarily because of the small mesh sizes used in the main body of the net, typically lower $20 \mathrm{~mm}$ (Marçalo et al., 2019). Therefore, the release of unwanted catch (UWC) generally happens by "slipping" all or part of the UWC out of the net while it is still in the water or by "discarding", when the catch is taken aboard and any unwanted components are removed and returned to the sea alive or dead (Marçalo et al., 2019).

Releasing or slipping is not a new strategy to remove unwanted catch from the purse seine net. Slipping of the entire or portion of the catch from the purse-seine is a common practice method due to a variety of economic (catch quality, market price/demand) and regulatory (quotas, sizes, protected species) drivers in European Atlantic waters (Marçalo et al., 2019). Due to aforementioned reasons, there has been a common practice of discarding unwanted catch by rolling the fish over the headline of purse seine net in British mackerel fishery (Lockwood et al., 1983), in western Australian Sardinops (Sardinops sagax) fishery (Mitchell et al., 2002), in Norwegian mackerel (Huse and Vold, 2010) and herring (Clupea harengus) (Tenningen et al., 2012) fisheries, in Spanish anchovy fishery and Portuguese sardine fishery (Marçalo et al., 2019). In these processes, entire or part of the catch is released by rolling the fish over the headline (floating line) of the net after partially hauling or drying-up the net. However, a modified slipping procedure is developed by Marçalo et al. (2018) enable the fish to escape through an opening (escape window) created by adding weights to the float line. In this procedure, the net was bunted (manually hauled) and $4 \pm 5$ sets of $10 \mathrm{~kg}$ weights were put along the headline to form an escape opening. In the slipping, sardines freely swimming out of the net through the opening.

When the slipping not performed in good conditions, it can cause highly significant mortality in released fish. Unacceptability high rates of mortality resulted by the conventional slipping for mackerel (Lockwood et al., 1983; Huse and Vold, 2010), herring (Tenningen et al., 2012), sardine (Stratoudakis and Marçalo, 2002; Marçalo et al., 2006; Marçalo et al., 2010) and Sardinops (Mitchell et al., 2002). However, various modified slipping procedures tested by Huse and Vold (2010) and Marçola et al. (2018) significantly reduced the highly significant mortality.

Excluding a substantial amount of jellyfish is a common slipping process in the Sea of Marmara purse seine fishery (Tosunoğlu and Kasapoğlu, 2019). Experienced skippers of the purse seiners have developed a different slipping process to exclude jellyfish in the Sea of Marmara for a long time. For this aim, a sheet of netting piece, larger mesh size, and thicker diameter, rigged on the bunt-end of the net. First of all, 
jellyfishes are intensified in the bunt of the net, just like fish and bycatch with the crew hauling the net aboard the vessel by manually. When reached the netting piece, the crew haul only the netting so that fishes pass the larger mesh while jellyfish retained on the net. At the latest stage, the jellyfish on the netting piece is slipped by rolling over the headline (floating line) of the net after partially hauling or drying-up the net while it is still in the water (Figure 1). After the slipping finalized, the netting sheet is opened from side-end and the fish pump is submerged to concentrated fish in the bunt-end section for the transfer of the fish to the deck of vessel. The main purpose of the study is to introduce the slipping process only used by the Sea of Marmara purse seine fishery. In addition, it is roughly to estimate about the amount of slipped jellyfish.

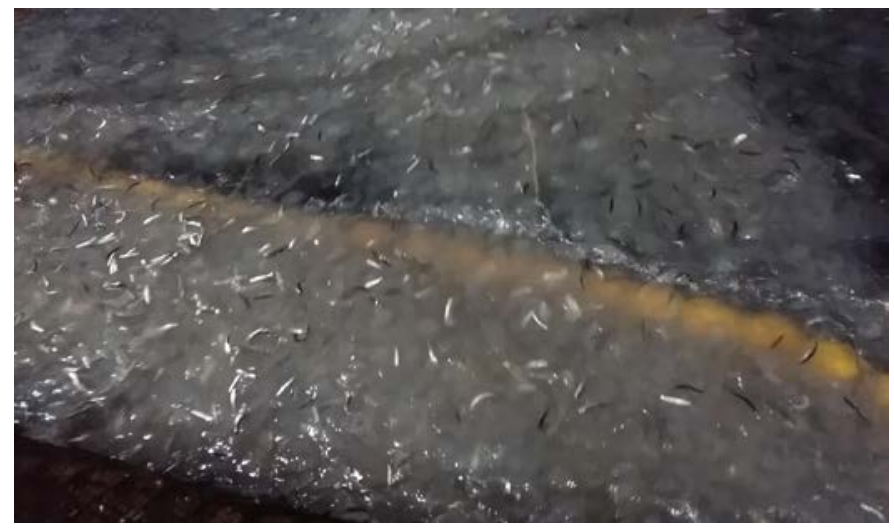

Figure 1. Jellyfish slipping over the headline from the bunt-end section of a purse seine net in the Sea of Marmara

\section{Material and Methods}

In the Sea of Marmara purse seine fishery, a shoal of fish is commonly aggregated to artificial light or rarely detected by the sonar. The season of fishing with light is restricted between 15 September and 31 October. Once, the skipper evaluates the fish composition, shoal size, and chances of capturing the aggregation, and then the purse seine vessel sets the net around the aggregated fish to quickly encircle them within the purse seine net. When the shape of net becomes a circular, purse seine vessel and skiff come back together and the gear is closed by hauling the purse line running through the rings at the bottom of the net (pursing). Then, until the volume of the net becomes smaller, the net is pulled out of the water and stacked back on the deck of fishing boat with the aid of the hydraulic power block and the crew (hauling). The concentrated fish (dense mass) in the section of net which is hauled last (bunt-end) in is transferred by a fish pump to the sieve on the deck of the vessel. This final stage of hauling (crowding in the bunt) is often done manually (i.e. with the crew hauling the net aboard the vessel by hand). After the catch is inspected, if the decision is made to harvest it, it is then transferred it into the boat. If the catch volume is lower, a larger scoop called kital or netting sheet is used by driven of a winch otherwise fish pump is engaged.

Table 1. Details of the purse seine operations in the Sea of Marmara

\begin{tabular}{|c|c|c|c|c|c|c|c|c|c|}
\hline Date & Operation & Vessel & Coordinates & $\begin{array}{c}\text { Depth } \\
(\mathrm{m})\end{array}$ & $\begin{array}{c}\text { Shoal } \\
\text { depth }(\mathrm{m})\end{array}$ & $\begin{array}{c}\text { Light duration } \\
(\min )\end{array}$ & Wind & $\begin{array}{l}\text { Net length } \\
\text { (m) }\end{array}$ & $\begin{array}{c}\text { Net depth } \\
\text { (m) }\end{array}$ \\
\hline 8-9.10.2018 & 1 & A & $\begin{array}{l}40^{\circ} 44^{\prime} 073^{\prime \prime} \mathrm{N} \\
29^{\circ} 17^{\prime} 237^{\prime \prime} \mathrm{E}\end{array}$ & 366 & $10-40$ & $20.30-12.50(260)$ & North 2-4 & 840 & 146 \\
\hline \multirow{5}{*}{$9-10.10 .2018$} & 2 & A & $\begin{array}{l}40^{\circ} 44^{\prime} 668^{\prime \prime} \mathrm{N} \\
29^{\circ} 17^{\prime} 486^{\prime \prime} \mathrm{E}\end{array}$ & 201 & $10-30$ & $01.15-03.15(120)$ & North 2-4 & 840 & 146 \\
\hline & 3 & A & $\begin{array}{l}40^{\circ} 41^{\prime} 134^{\prime \prime} \mathrm{N} \\
29^{\circ} 16^{\prime} 215^{\prime \prime} \mathrm{E}\end{array}$ & 397 & $10-20$ & $05.15-05.45(30)$ & North 1-2 & 840 & 146 \\
\hline & 1 & $\mathrm{~B}$ & $\begin{array}{l}40^{\circ} 53^{\prime} 142^{\prime \prime} \mathrm{N} \\
28^{\circ} 40^{\prime} 848^{\prime \prime} \mathrm{E}\end{array}$ & 677 & $10-40$ & $22.00-01.00(180)$ & North 2-4 & $600(720)$ & 164 \\
\hline & 2 & $\mathrm{~B}$ & $\begin{array}{l}40^{\circ} 52^{\prime} 543^{\prime \prime} \mathrm{N} \\
28^{\circ} 41^{\prime} 062^{\prime \prime} \mathrm{E}\end{array}$ & 183 & $10-20$ & $04.00-05.15(75)$ & North 2-4 & $600(720)$ & 164 \\
\hline & 1 & $\mathrm{C}$ & $\begin{array}{l}40^{\circ} 47^{\prime} 238^{\prime \prime} \mathrm{N} \\
29^{\circ} 09^{\prime} 917^{\prime} \mathrm{E}\end{array}$ & 220 & $10-20$ & $22.30-00.30(120)$ & North 3-5 & $600(800)$ & 164 \\
\hline \multirow{3}{*}{$10-11.10 .2018$} & 2 & $\mathrm{C}$ & $\begin{array}{l}40^{\circ} 46^{\prime} 164^{\prime \prime} \mathrm{N} \\
29^{\circ} 10^{\prime} 273^{\prime \prime} \mathrm{E}\end{array}$ & 329 & $10-20$ & $01.15-03.15(120)$ & North 2-4 & $600(800)$ & 164 \\
\hline & 1 & $\mathrm{~B}$ & $\begin{array}{l}40^{\circ} 56^{\prime} 575^{\prime} \mathrm{N} \\
28^{\circ} 44^{\prime} 802^{\prime \prime} \mathrm{E}\end{array}$ & 92 & $10-20$ & $01.10-03.10(120)$ & North 2-4 & $600(720)$ & 164 \\
\hline & 2 & $\mathrm{~B}$ & $\begin{array}{l}40^{\circ} 55^{\prime} 691 ” \mathrm{~N} \\
28^{\circ} 43^{\prime} 936^{\prime \prime} \mathrm{E}\end{array}$ & 77 & $10-30$ & $04.30-06.30(120)$ & North 2-4 & $600(720)$ & 164 \\
\hline
\end{tabular}


There were eight successfully purse seine operation realized during the study period in the Sea of Marmara (Figure 2). However, one operation was abandoned due to aggregation of the fish shoal under the light vessel was not enough amount to catch it. Stages of operation in the first paragraph, details regarding the purse seine operations and vessels characteristics used are given in Table 1 and Table 2, respectively.

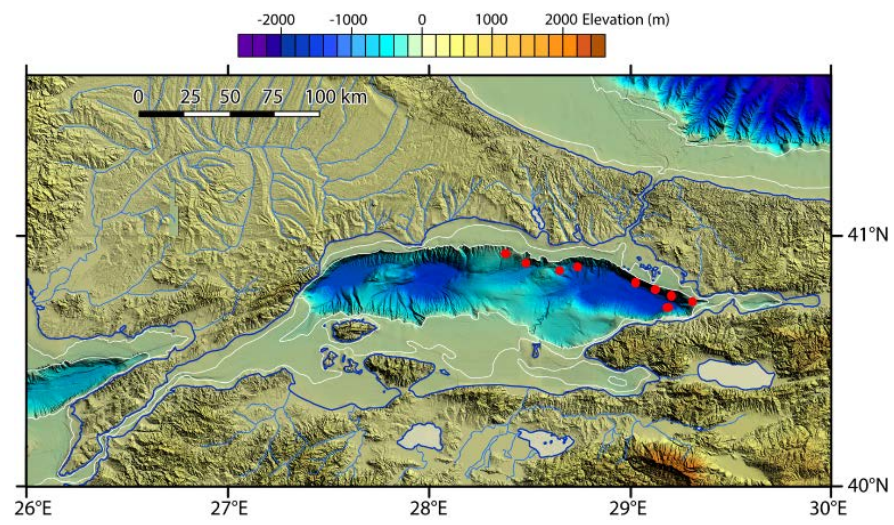

Figure 2. Purse seine operation locations realized in the Sea of Marmara

The operating depths were greater than the depth of purse seine net in seven operations whereas only two were shallower (Table 1). Captured shoals generally detected at 10-20 m depth ranges in water column by echo-sounder. During the study period, the moon was in the dark phase. For this reason, the duration of the artificial light was changed between 30 and 180 min generally $120 \mathrm{~min}$. Four operations were realized by the purse seiner $\mathrm{B}$ and her light vessel $\mathrm{Bb}$, three operations by $\mathrm{A}$ and $\mathrm{Aa}$ and two operations $\mathrm{C}$ and $\mathrm{Cc}$ (Table 1 and Table 2). The full lengths of the nets in many operations were not used depending on the size of the shoals aggregated under the light vessel.

On the contrary to traditional using in the Sea of Marmara, a slipping method was adapted in purse seine fishing targeted anchovy, horse mackerels and bluefish to release jellyfish by scrolling a special netting sheet from the bunt-end section of the net which called pelte net in the Turkish fishermen. Details of the netting piece (drawn in green) rigged over the bunt-end were given without scale for only anchovy purse seine in figure 3. The pelte net consists of a $45 \times 45 \mathrm{~m}$ square netting piece. The mesh size and thickness of the net is $68 \mathrm{~mm}$ and $210 \mathrm{~d} / 72 \mathrm{no}$, respectively. Thanks to pelte net, larger sizes of commercial fish, vulnerable species (shark and rays) and cetacean can pass through the meshes of the net and easily slipped by the net and roll over the floating line of the purse seine net. All the sides of net except left are rigged strictly to the bunt-end. Left side is always open, because the net is opened from this side and aggregated fish in the bunt-end is transferred by a fish pump on the deck of the purse seiner, easily.

The mesh size of the purse seine nets was $15 \mathrm{~mm}$ because the size of the targeted fish anchovy was a small pelagic. To estimate total catch of anchovy, styrofoam fish boxes filled with the fishes were converted to $\mathrm{kg}$ (each of $15 \mathrm{~kg}$ ). In addition, the amount of jellyfish estimated visually confirmed by experienced skipper and crew just like Huse and Vold (2010). Difference between landed and slipped fish amounts was assessed using a Student's t-test.

Table 2. Technical characteristics of the purse seiners and light vessels

\begin{tabular}{|c|c|c|c|c|c|c|}
\hline & Main Vessel & Light Vessel & Main Vessel & Light Vessel & Main Vessel & Light Vessel \\
\hline & $A$ & $A a$ & B & $B b$ & C & $C c$ \\
\hline Width (m) & 8.0 & 2.9 & 11.0 & 4.6 & 9.2 & 8.4 \\
\hline Gross tonnage (GRT) & 213 & 7.17 & 202 & 14.08 & 189 & 9.5 \\
\hline Main engine $(\mathrm{kW})$ & 581.88 & 126.87 & 448.51 & 104.44 & 601.00 & 100.7 \\
\hline Auxiliary engine $(\mathrm{kW})$ & 487.14 & & & & 434.17 & \\
\hline Building Year & 1989 & 1987 & 2018 & 2006 & 1993 & 1988 \\
\hline
\end{tabular}




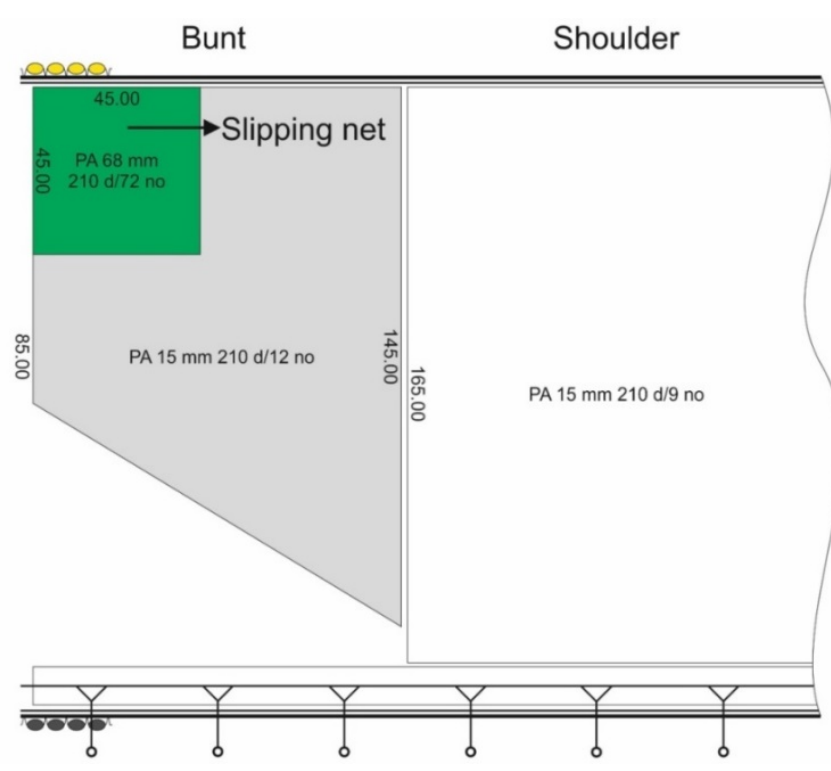

Figure 3. Slipping netting piece (in green square) rigged on bunt-end of the purse seine net

\section{Results}

The percentage of landed species versus to jellyfish varied between \%23 and \%85 and mean percentage of landed fish is nearly same like slipped jellyfish. There was no statistical difference between amount of landed and slipped fish $(\mathrm{p}=0.790)$. The maximum landed amount of fish is $10755.8 \mathrm{~kg}$, whereas slipped jellyfish is $7800.0 \mathrm{~kg}$. The percentage of jellyfish amount is not same for all the operations (Table 3).

Table 3. Catch amounts and percentages of landed and slipped fishes in the Sea of Marmara purse seine fishery

\begin{tabular}{lrrrrr}
\hline & \multicolumn{2}{c}{ Catch Amount (kg) } & \multicolumn{2}{c}{ Percent (\%) } \\
\hline Haul & Landed & Slipped & Total & Landed & Slipped \\
\hline 1 & 1519.9 & 5021.5 & 6541.4 & 23 & 77 \\
2 & 1655.6 & 4510.6 & 6166.2 & 27 & 73 \\
3 & 9804.8 & 3150.0 & 12954.8 & 76 & 24 \\
4 & 3400.4 & 600.0 & 4000.4 & 85 & 15 \\
5 & 2311.1 & 7800.0 & 10111.1 & 23 & 77 \\
6 & 10755.8 & 6103.3 & 16859.1 & 64 & 36 \\
7 & 1470.0 & 1200.0 & 2670.0 & 55 & 45 \\
8 & 4200.2 & 3301.2 & 7501.4 & 56 & 44 \\
Total & 35117.7 & 31686.6 & 66804.2 & 53 & 47 \\
\hline
\end{tabular}

Anchovy is the most important landed fish species for the Sea of Marmara purse seine fishery in this period. The mean landed amount is $4379( \pm 3756.6) \mathrm{kg}$ for per operation. The mean slipped amount of jellyfish is $3812.5( \pm 2404.4) \mathrm{kg}$.
However, both anchovy and jellyfish are the vast majority species that landed and slipped, respectively (Table 4).

While anchovy constituted $99.8 \%$ of the landed species, slipped jellyfish percentage was $96.3 \%$ (Figure 4). In the beginning of fishing season anchovy is the only dominated fish species that targeted by the purse seiners. Very little amount (86 $\mathrm{kg}$ ) of horse mackerel, Atlantic bonito, garfish, sprat, sardine, bluefish etc. caught as by-catch (Table 5). Approximately 100 boxes of anchovy $(1180 \mathrm{~kg})$ also slipped with the jellyfish releasing operations. In the operations larger size two shark individuals and bonito individuals were seen over the netting sheet. While the bonito individuals collected by a scoop net over the netting piece, the sharks were slipped to the sea over the floating line of the net.

Table 4. Descriptive statistics of the landed (anchovy) and slipped (jellyfish) fishes in the Sea of Marmara purse seine fishery

\begin{tabular}{lrrrrr}
\hline Statistics & Anchovy & Landed & Jellyfish & Slipped & Total \\
\hline Mean & 4379.0 & 4389.7 & 3812.5 & 3960.8 & 8350.5 \\
Standard error & 1328.2 & 1332.4 & 850.1 & 853.2 & 1672.5 \\
Standard deviation & 3756.6 & 3768.7 & 2404.4 & 2413.2 & 4730.6 \\
Range & 9230 & 9286 & 7000 & 7200 & 14189 \\
Minimum & 1470 & 1470 & 500 & 600 & 2670 \\
Maximum & 10700 & 10756 & 7500 & 7800 & 16859 \\
Total & 35032 & 35118 & 30500 & 31687 & 66804 \\
\hline
\end{tabular}

Table 5. Landing and slipped amounts of fish species caught by purse seiners in the Sea of Marmara

\begin{tabular}{lr|lr}
\hline \multicolumn{2}{c|}{ Landed } & \multicolumn{2}{c}{ Slipped } \\
\hline Species & Amounts $(\boldsymbol{k g})$ & Species & Amounts $(\mathbf{k g})$ \\
\hline Anchovy & 35032.0 & Jellyfish & 30500.0 \\
Horse mackerel & 72.1 & Anchovy & 1180.0 \\
Atlantic bonito & 5.5 & Atlantic bonito & 4.3 \\
Garfish & 2.9 & Shark & 2.3 \\
Sprat & 1.8 & \\
Sardine & 1.7 & \\
Bluefish & 1.0 & \\
Chub mackerel & 0.3 & \\
Round sardine & 0.2 & \\
Golden mullet & 0.2 & \\
Whiting & 0.1 & \\
Seahorse & 0.02 & \\
Total & 35117.7 & Total \\
\hline
\end{tabular}



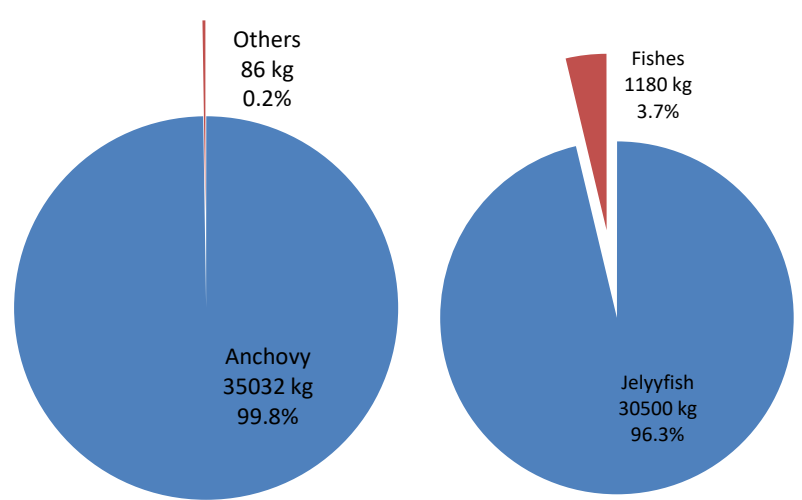

Figure 4. Landed (a) and slipped (b) amounts and percentages of fishes

\section{Discussion}

In this study, a different slipping procedure to exclude jellyfish from the captured commercial fish in the bunt-end of the purse seine net was investigated for the first time in the Sea of Marmara. The purpose of the slipping process is totally different from conventional slipping procedure used by North Atlantic countries e.g. Norway, Portugal and Spain (Marçalo et al., 2019). In an ordinary or modified slipping procedure, the crowded fishes in the bunt-end of a purse seine net are released over the headline of the net for the market (quality) and regulation (size and quota) reasons. However, in this procedure that used only in the Sea of Marmara as far as we know, the unwanted jellyfish excluded by roll over headline of the bunt end of the purse seine net by a special netting which has a larger mesh size and thicker diameter. All the purse seiners occupy only in the Sea of Marmara have to use the special netting for operational and handling reasons. Because, it is impossible that commercial catch does not separate from jellyfish when the mixed fish and jellyfish directly goes pump to the deck by purse seiner.

In the excluding operations, a little amount of commercial catch (anchovy) released over the headline of the purse seine nets. However, this amount is very small when compared to the total jellyfish amount (approximately 1/30). In the meanwhile, larger sizes commercial species such as Atlantic bonito and unwanted species shark were seen over the netting piece before slipping practise started. Excluding of jellyfish started after individuals of bonitos were picked up by a scoop in a short time ( $2 \mathrm{~min}$ ). Sharks were seen alive during the slipping process. Although this process thought to be useful for the survival of the larger vulnerable species, the complete pulling up and ultimately slipping over the headline causes more physical injury and reduces the probability of survival of slipped small size pelagic fish (Marçalo et al., 2018). Since survival of the jellyfish and little amount of anchovy after excluded from buntend of the purse seine net is not known, this issue should be examined by scientific methods. Slipping practises are rarely applied by the Aegean purse seiner in Turkey for regulation and market reasons. However, there is no information regarding slipping amount and the survival rate of the species caught by the purse seiner.

Survival ratio of slipped species can be affected by different factors such as holding time and catch density in the bunt, size of the fish and condition factor, scale loss and water temperature (Marçalo et al., 2018). In the bunt, the catch can become highly crowded, and can be fatally harmed by oxygen depletion, exhaustion and physical injury from contact with the net and catch (Tenningen et al., 2012). The mortality is directly related to their treatment within the bunt-end and increase with density and crowding duration (Lockwood et al., 1983; Tenningen et al., 2012; Marçalo et al., 2010). In the slipping process, before the catch does not become too crowded, survival can be higher. If the whole catch is to be released, the bunt end/wing is opened and several purse rings are released (Marçalo et al., 2019). However, if only a portion of the catch is to be released, opening must be adjusted carefully. According to European Union regulations, slipping of mackerel and herring is completed before $80 \% / 90 \%$ of the net has been hauled (the point of retrieval) in NW waters and the North Sea (Marçalo et al., 2019).

\section{Conclusion}

Although slipping practised rarely in Turkey, all the purse seiner in the Sea of Marmara have to use the adapted slipped process to get rid of jellyfish. However, there are no records and scientific findings regarding slipped amount of the jellyfish. For this reason, this study is important to presented preliminary results regarding amount of the jellyfish. In conclusion, this study is extended completely the Sea of Marmara practised to understand the dimensions of jellyfish amount and slipping process.

\section{Acknowledgements}

This research funded by the Ministry of Agriculture and Forestry, General Directorate Agriculture Research and Policies (Grant number: TAGEM/HAYSUD/2015/A11/P02/8). We thank to Dr. Elvan Atılgan, Dr. İlkay Özcan Akpınar, Dr. Gaye Doğan and Mr. İrfan S. Soysal for assisting and logistic supports during the field surveys and Prof. Dr. Ali Aksu (Memorial University of Newfoundland, Canada) for drawing map of the Sea of Marmara. 


\section{Compliance with Ethical Standards}

\section{Authors' Contributions}

Authors contributed equally to this work.

\section{Conflict of Interest}

The authors declare that there is no conflict of interest.

\section{Ethical Approval}

For this type of study, formal consent is not required.

\section{References}

Breen, M., Isaksen, B., Ona, E., Pedersen, A. O., Pedersen, G., Saltskår, J., Svardal, B., Tenningen, M., Thomas, P. T., Totland, B., Øvredal, J. T. \& Vold, A. (2012). A review of possible mitigation measures for reducing mortality caused by slipping from purse-seine fisheries. ICES CM 2012/C: 12.

Daskalov, G. M., Grishin, A. N., Rodionov, S. \& Mihneva, V. (2007). Trophic cascades triggered by overfishing reveal possible mechanisms of ecosystem regime shifts. Proceedings of the National Academy of Sciences, 104: 10518-10523.

Handegard, N. O., Tenningen, M., Howarth, K., Anders, N., Rieucau, G. \& Breen, M. (2017). Effects on schooling function in mackerel of sub-lethal capture related stressors: Crowding and hypoxia. PLoS ONE, 12(12): e0190259. $\quad$ https://doi.org/10.1371/journal.pone. $\underline{0190259}$

Huse, I., \& Vold, A. (2010). Mortality of mackerel (Scomber scombrus L.) after pursing and slipping from a purse seine. Fisheries Research, 106: 54-59. https://doi.org/10.1016/j.fishres.2010.07.001

İşinibilir, M. \& Yılmaz, İ. N. (2016). Jellyfish species in the Sea of Marmara (pp. 390-400). In E. Özsoy, M. N. Çağatay, N. Balkıs, N. Balkıs, B. Öztürk (Eds.), The Sea of Marmara: Marine Biodiversity, Fisheries, Conservation and Governance. Istanbul: Turkish Marine Research Foundation (TUDAV), Publication No. 42.

Lockwood, S. J., Pawson, M. G. \& Eaton, D. R. (1983). The effects of crowding on mackerel (Scomber scombrus L.) - Physical condition and mortality. Fisheries Research, 2: 129-147. https://doi.org/10.1016/0165-7836(83)90114-5
Marçalo, A., Breen, M., Tenningen, M., Onandia, I., Arregi, L. \& Gonçalves, J. M. S. (2019). Mitigating slipping-related mortality from purse seine fisheries for small pelagic fish: case studies from European Atlantic waters (pp. 297-318). In S. S. Uhlmann, C. Ulrich, S. J. Kennelly (Eds), The European Landing Obligation. Switzerland: Springer Nature.

Marçalo, A., Guerreiro, P. M., Bentes, L., Rangel, M., Monteiro, P., Oliveira, F., Afonso, C. M. L., Pousão-Ferreira, P., Benoît, H. P., Breen, M., Erzini, K. \& Gonçalves, J. M. S. (2018). Effects of different slipping methods on the mortality of sardine, Sardina pilchardus, after purseseine capture off the Portuguese Southern coast (Algarve). PLoS ONE, 13(5): e0195433. https://doi.org/ 10.1371/journal.pone.0195433

Marçalo, A., Marques, T. A., Araújo, J., Pousão-Ferreira, P., Erzini, K. \& Stratoudakis, Y. (2010). Fishing simulation experiments for predicting the effects of purse-seine capture on sardine (Sardina pilchardus). ICES Journal of Marine Science, 67: 334-344. https://doi.org/ $\underline{10.1093 / \text { icesjms/fsp244 }}$

Marçalo, A., Mateus, L., Duarte Correira, J. H., Serra, P., Fryer, R. \& Stratoudakis, Y. (2006). Sardine (Sardina pilchardus) stress reactions to purse seine fishing. Marine Biology, 149: 1509-1518. https://doi.org/ 10.1007/s00227-006-0277-5

Mitchell, R. W., Blight, S. J., Gaughan, D. J. \& Wright, I. W. (2002). Does the mortality of released Sardinops sagax increase if rolled over the headline of a purse seine net? Fisheries Research, 57: 279-285. https://doi.org/10.1016/ S0165-7836(01)00354-X

Stratoudakis, Y. \& Marçalo, A. (2002). Sardine slipping during purse-seining off northern Portugal. ICES Journal of Marine Science, 59: 1256-1262. https://doi.org/10.1006/ jmsc.2002.131

Tenningen, M, Vold, A. \& Olsen, R. E. (2012). The response of herring to high crowding densities in purse-seines: survival and stress reaction. ICES Journal of Marine Science, 69: 1523-1531. https://doi.org/10.1093/icesjms/ $\underline{\text { fss114 }}$

Tosunoğlu, Z. \& Kasapoğlu, N. (2019). Slipping practises in Turkish purse seine fishery. Proceedings of the International Biodiversity and Ecology Sciences Symposium, Turkey pp. 82-85.

TurkStat. (2018). Fisheries statistics 2017 (in Turkish). Ankara: Turkish Statistic Institution. 
Watson, R., Revenga, C. \& Kura, Y. (2006). Fishing gear associated with global marine catches. I Database development. Fisheries Research, 79: 97-102. https://doi.org/10.1016/j.fishres.2006.01.010

Yıldız, T. \& Karakulak, F. S. (2016). Traditional fishing in the Sea of Marmara: from the past to the present (pp. 697709). In E. Özsoy, M. N. Çağatay, N. Balkıs, N. Balkıs, B. Öztürk (Eds.), The Sea of Marmara: Marine Biodiversity, Fisheries, Conservation and Governance. Istanbul: Turkish Marine Research Foundation (TUDAV), Publication No. 42.
Yüksek, A. (2016). Biodiversity of Sea of Marmara and the affecting factors (pp. 570-580). In E. Özsoy, M. N. Çağatay, N. Balkıs, N. Balkıs, B. Öztürk (Eds.), The Sea of Marmara; Marine Biodiversity, Fisheries, Conservation and Governance. Istanbul: Turkish Marine Research Foundation (TUDAV), Publication No. 42. 